\author{
E. Çopuroğlu ${ }^{1}$, T. Mehmetoğlu ${ }^{2}$ \\ ${ }^{l}$ Department of Physics, Faculty of Arts and Sciences, Gaziosmanpaşa University, Tokat, Turkey; \\ ${ }^{2}$ Amasya University, Taşova Vocational School, Turkey \\ (E-mail: ebrucopuroglu@gmail.com)
}

\title{
Analytical evaluation of the Uehling potential using binomial expansion theorems
}

\begin{abstract}
In this paper, we have introduced a new method to study of Uehling potential using binomial expansion theorems. Note that, the Uehling potential is a powerful tool to determine the effect of vacuum polarization in atomic and muon-atomic systems. The correcting of vacuum-polarization for an electron in a nuclear Coulomb field can be defined more precisely by the use of Uehling potential. From this point of view, the determination of explicit and closed-form analytical expressions for Uehling potential is very important. Therefore, presented method is illustrated by analytically calculation of the Uehling potential with the simple binomial coefficients and exponential integral functions. As can be seen from table and figure, the newly derived analytical expression well avoids the computational difficulties. An evaluation analysis of the Uehling potential is reported for arbitrary values of parameters. Because of its simple form the suggested method can be generally applied to the quantum thermodynamical problems.
\end{abstract}

Keywords: Uehling potential, vacuum polarization, quantum electrodynamics, Bickley-Naylor functions, Exponential integral function.

\section{Introduction}

The interaction potential between two electric charges which contains an additional term responsible for the electric polarization of the vacuum was introduced by Uehling [1], and has seen a series of successful applications in quantum electrodynamics (QED) [2-10]. This formalism can be applied to the effect of vacuum polarization itself and for various electrons and atoms [11]. Note that the Uehling potential is the integral function, therefore, before applying to the physical problems it should be analytically evaluated. Unfortunately, there are limited numbers of studies in literature for the analytical evaluation methods of Uehling potential. In this sense, recently, Frolov $[2,11]$ has suggested an efficient and useful analytical approximation by using Bickley-Naylor functions and modified Bessel function of zero order. The Bickley-Naylor functions are one of the conceptual tools in the nuclear computational science [11-15]. Therefore, obtaining the efficient formulae for the any order Bickley-Naylor functions has significant role in physical applications of Uehling potential. For the analytical evaluation of the first and second order Bickley-Naylor functions author has proposed new formulae [12].

In the present article, by using binomial expansion theorems, we propose a new formula in terms of exponential integral functions occurring one infinite sum which enables fast and accurate evaluation of the Uehling potential. The new analytical approach for evaluating the Uehling potential is conceptually simpler than existing methods in the literature.

\section{Definition and basic formulas}

The interaction potential of two-point particles with including the vacuum polarization is described by $[1,2]$ :

$$
\phi(r)=\frac{Q e}{r}\left[1+\frac{2 \alpha}{3 \pi} \int_{1}^{\infty} e^{-2 \alpha^{-1} r t}\left(1+\frac{1}{2 t^{2}}\right) \frac{\sqrt{t^{2}-1}}{t^{2}} d t\right] .
$$

The Eq. (1) in the atomic units systems can be rewritten as:

$$
\phi(r)=\frac{Q}{r}+\frac{2 \alpha Q}{3 \pi} \int_{1}^{\infty} e^{-2 \alpha^{-1} r t}\left(1+\frac{1}{2 t^{2}}\right) \frac{\sqrt{t^{2}-1}}{t^{2}} d t=\frac{Q}{r}+U(r),
$$

where $Q$ is electric charge, $\alpha$ is fine structure constant $\left(\alpha^{-1} \approx 137.03599911\right)$ and $U(r)$ is Uehling potential determined as: 


$$
U(r)=\frac{2 \alpha Q}{3 \pi} I(r)
$$

Here $I(r)$ is the Uehling function defined as:

$$
I(r)=\int_{1}^{\infty} e^{-2 \alpha^{-1} r t}\left(1+\frac{1}{2 t^{2}}\right) \frac{\sqrt{t^{2}-1}}{t^{2}} d t .
$$

In study [2] useful formulae have obtained for Uehling potential in following form:

$$
\begin{gathered}
U(a)=\frac{4 Q}{3 \pi a}\left[\left(1+\frac{a^{2}}{12}\right) K i_{0}(a)-\frac{a}{12} K i_{1}(a)-\left(\frac{a^{2}}{12}+\frac{5}{6}\right) K i_{2}(a)\right], \\
U(a)=\frac{4 Q}{3 \pi a}\left[K i_{0}(a)-\frac{1}{2} K i_{2}(a)-\frac{1}{2} K i_{4}(a)\right],
\end{gathered}
$$

where $a=2 \alpha^{-1} r$. Here $K i_{n}(x)$ are the Bickley-Naylor functions determined as:

$$
K i_{n}(x)=\int_{0}^{\infty} \frac{\exp (-x \cosh t)}{\cosh ^{n} t} d t
$$

Notice that in special case of $n=0$ Bickley-Naylor functions reduce to the Bessel functions $K i_{0}(x)=K_{0}(x)$ and defined as:

$$
K i_{0}(x)=K_{0}(x)=\sum_{k=0}^{\infty}(\psi(k+1)+\ln 2-\ln x) \frac{x^{k}}{2^{2 k}(k !)^{2}},
$$

where $\psi(k+1)$ is the Euler Function defined following as:

$$
\psi(k+1)=-\gamma-\sum_{i=1}^{\infty} \frac{(-1)^{i} F_{i}(k)}{i} .
$$

Here $\gamma$ is the well known Euler's constant. For $n \geq 2$, Bickley-Naylor functions can be evaluated by the following recursive formula [13]:

$$
n K i_{n+1}(x)=(n-1) K i_{n-1}(x)-x K i_{n}(x)+x K i_{n-2}(x) .
$$

Note that for the calculation of Uehling potential by using Eq. (5), the $K i_{1}(a)$ and $K i_{2}(a)$ Bickley-Naylor functions must be determined. It is clear from the literature that there is not enough and efficient studies for the evaluation of these functions. Beside these insufficiencies recently the author [12] has given accurate formulae for the one and second order Bickley-Naylor functions in his study as following:

$$
\begin{aligned}
K i_{1}(x)= & \frac{\pi}{2}+x[\gamma+\ln (x / 2)] \sum_{k=0}^{\infty} \frac{(x / 2)^{2 k}}{(k !)^{2}(2 k+1)}-x \sum_{k=0}^{\infty} \frac{(x / 2)^{2 k}}{(k !)^{2}(2 k+1)^{2}} \\
& -x \sum_{k=0}^{\infty} \frac{(x / 2)^{2 k} \Phi(k+1)}{(k !)^{2}(2 k+1)}, \\
K i_{2}(x)= & 1-\frac{\pi}{2} x+\frac{x^{2}}{2}[\gamma+\ln (x / 2)] \sum_{k=0}^{\infty} \frac{(x / 2)^{2 k}}{(k !)^{2}(k+1) !(2 k+1)}+\frac{x^{2}}{4} \sum_{k=0}^{\infty} \frac{(4 k+3)(x / 2)^{2 k}}{[(k+1) !(2 k+1)]^{2}} \\
+ & \frac{x^{2}}{2} \sum_{k=0}^{\infty} \frac{(x / 2)^{2 k} \Phi(k+1)}{(k !)^{2}(k+1) !(2 k+1)} .
\end{aligned}
$$

Here $\Phi(k+1)$ functions are determined as:

$$
\Phi(k+1)=1+\frac{1}{2}+\frac{1}{3}+\ldots .+\frac{1}{k} .
$$


The calculation tests show that it is necessary to give various accurate and efficient analytical formulae for the evaluation of Uehling potential. The objective of this paper is to derive basic analytical expression for the Uehling potential. For this purpose we use binomial expansion theorems for the evaluation of Uehling potential. The binomial expansion theorem can be demonstrated by $[13,15]$ :

$$
(x \pm y)^{n}=\sum_{m=0}^{N}( \pm 1)^{m} f_{m}(n) x^{n-m} y^{m},
$$

here $f_{m}(n)$ are the binomial functions given as:

$$
f_{m}(n)=\left\{\begin{array}{ll}
\frac{1}{m !} \prod_{i=0}^{m-1}(n-i) & \text { for integer } n \\
\frac{(-1)^{m} \Gamma(m-n)}{m ! \Gamma(-n)} & \text { for noninteger } n
\end{array} .\right.
$$

With the help of binomial expansion theorem we can rewrite Eq. (4) given for the Uehling potential following as:

$$
I(a)=\lim _{N \rightarrow \infty} \sum_{i=0}^{N} F_{i}(1 / 2)(-1)^{i}\left[E_{1+2 i}(a)+\frac{1}{2} E_{3+2 i}(a)\right] .
$$

Here $E_{n}(t)$ is the exponential integral function determined by:

$$
\begin{gathered}
E_{n}(t)=\int_{1}^{\infty} \frac{e^{-t y}}{y^{n}} d y, \\
E_{n}(t)=t^{n-1} \Gamma(1-n, t) .
\end{gathered}
$$

In Eqs. (15) and (18), the $\Gamma(\alpha)$ and $\Gamma(\alpha, x)$ are well known complete and incomplete Gamma functions, respectively (see Ref. $[13,15]$ for exact definition).

\section{Numerical Results and Discussion}

In this paper, a new formula for the analytical calculation of the Uehling potential is presented. The proposed algorithm is based on the binomial expansion theorem and exponential integral functions. The analytical evaluation allows us to calculate Uehling potential by using simple mathematical expressions. The obtained formulae were performed by using Turbo Pascal programming language. The computational results of Uehling potential for various values of parameters have been demonstrated in Table and Figure.

Comparison of obtained results by considering Eq. (16) and Eq. (5) for calculating Uehling function $(\mathrm{N}=450)$

\begin{tabular}{|c|c|c|}
\hline$r$ & Results of Eq. (16) & Results of Eq. (5) \\
\hline \hline 1 & 2 & 3 \\
\hline 0.01 & 8.115051 & 8.115036 \\
\hline 00.2 & 7.422076 & 7.422061 \\
\hline 0.2 & 5.122582 & 5.122568 \\
\hline 0.5 & 4.211433 & 4.211418 \\
\hline 1 & 3.526823 & 3.526809 \\
\hline 1.5 & 3.129856 & 3.1298421 \\
\hline 2 & 2.850633 & 2.8506191 \\
\hline 5 & 1.984293 & 1.984275 \\
\hline 8 & 1.562901 & 1.562887 \\
\hline 10.5 & 1.330496 & 1.330483 \\
\hline 15.7 & 1.007708 & 1.007696 \\
\hline 20 & 0.828739 & 0.828728 \\
\hline
\end{tabular}




\begin{tabular}{|c|c|c|}
\hline 1 & 2 & 3 \\
\hline 25.2 & 0.670948 & 0.670938 \\
\hline 30 & 0.561539 & 0.561530 \\
\hline 35.9 & 0.458456 & 0.458447 \\
\hline 40.8 & 0.3913553 & 0.391347 \\
\hline 48.7 & 0.3077415 & 0.307734 \\
\hline 55 & 0.256683 & 0.256677 \\
\hline 60.9 & 0.218009 & 0.2180029 \\
\hline 100 & 0.0820734 & 0.0820701 \\
\hline 200 & 0.0098917 & 0.0098914 \\
\hline
\end{tabular}

In Table, our results have been compared with literature [2] and it is shown that obtained results are satisfactory. In Fig. 1, we plot our analytical and literature results for Uehling potential as a function of interparticle distance $r$. The solid and dashed curves represent our and literature data, respectively.

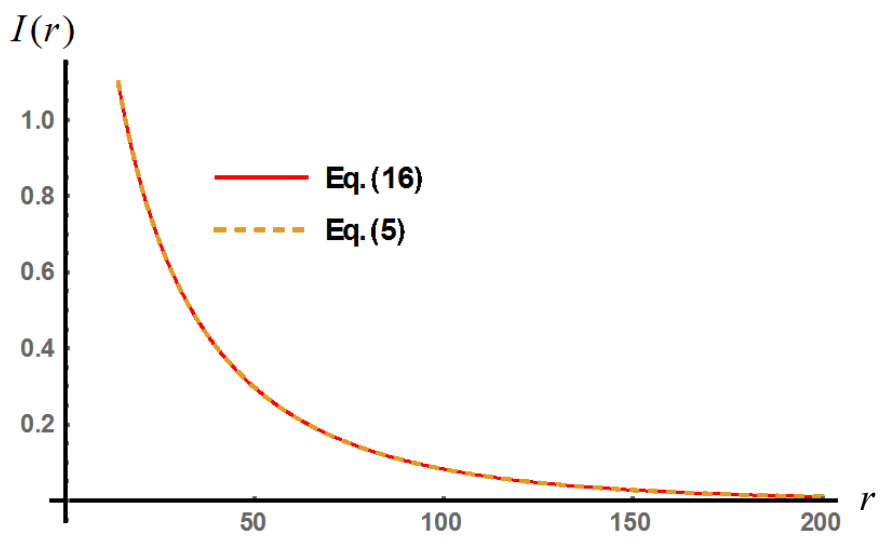

Figure. Using Eqs. (16) and (5), the values of Uehling function $I(r)$ with respect to interparticle distance $r$

Table and Figure show that our analytical algorithm is reliable and fast in a wide range interparticle distance $r$. For instance, in the case of $r=0.01$, the CPU times taken from the use of Eqs. (16) and (5) are $0.062 \mathrm{~ms}$ and $0.343 \mathrm{~ms}$, respectively. As a result, we made the calculation time about 20 times as fast with compared to the literature. Thus, we have proposed an alternative method for the evaluation of Uehling potential which has significant role in atomic and muon-atomic systems, especially the interaction potential between two electric charges.

\section{References}

1 Uehling, E.A. (1935). Polarization effects in the positron theory. Physical Review, 48(1), 55-62.

2 Frolov, A.M., \& Wardlaw, D.M. (2012). Analytical formula for the Uehling potential. The European Physical Journal B, 85(10), 348-350.

3 Dirac, P.A.M. (1930). The principles of quantum mechanics. The Clarendon Press.

4 Heisenberg, W. (1936). Euler H.Z. Physik, 38, 314-319.

5 Pauli, W., \& Villars, F. (1949). On the invariant regularization in relativistic quantum theory. Reviews of Modern Physics, 21(3), 434-444.

6 Akhiezer, A.I., \& Beresteskii, V.B. (1981). Quantum Electrodynamics, Nauka Science, Moscow.

7 Petelenz, P., \& Smith Jr, V.H. (1987). Exact matrix elements of the Uehling potential in a basis of explicitly correlated twoparticle functions. Physical Review A, 35(10), 4055-4059.

8 Frolov, A.M., \& Efros, V.D. (1984). Accurate solution method in the three-body problem and binding energies of mesic molecules. JETP Lett, 39(9), 544-547.

9 Frolov, A.M., \& Efros, V.D. (1985). An accurate method in the Coulomb three-body problem and muonic-molecule excited states, J. Phys. B, 18, L265-L270.

10 Gocheva, A.D., Gusev, V.V., Melezhik, V.S., Ponomarev, L.I., Puzynin, I.V., Puzynina, T.P, \& Vinitsky, S.I. (1985). High accuracy energy-level calculations of the rotational-vibrational weakly bound states of $\mathrm{dd} \mu$ and $\mathrm{dt} \mu$ mesic molecules. Physics Letters $B, 153(6), 349-352$. 
11 Frolov, A.M. (2012). On the properties of the Uehling potential. arXiv preprint arXiv:1210.6737.

12 Altaç, Z. (1996). Integrals involving Bickley and Bessel functions in radiative transfer, and generalized Exponential Integral functions. ASME J. Heat Transfer. 118 789-792.

13 Abramowitz, M., \& Stegun, I.A. (1972). Confluent hypergeometric functions. Ch, 13, 503-515.

14 Milgram, M.S. (1978). Analytic method for the numerical solution of the integral transport equation for a homogeneous cylinder. Nuclear Science and Engineering, 68(3), 249-269.

15 Copuroğlu, E., \& Mehmetolu, T. (2015). Full analytical evaluation of the Einstein relation for disordered semiconductors. IEEE Transactions on Electron Devices, 62(5), 1580-1583.

\title{
Э. Чопуроглу, Т. Мехметоглу \\ Биномиалдық жіктеу теоремасын қолдану арқылы Юлинг потенциалын аналитикалық жуықтап анықтау
}

\begin{abstract}
Мақалада Юлинг потенциалын талдаудың биномиалдық жіктеу теоремасына негізделген жаңа әдісі ұсынылған. Атомдық және мюон-атомдық жүйелерге вакуумның поляризациясын анықтауда Юлинг потенциалының алатын орны ерекше екендігі белгілі. Юлинг потенциалының көмегімен ядроның кулон өрісіндегі электрондарға вакуумның поляризациясының әсерін дәл анықтауға болады. Осы тұрғыдан Юлинг потенциалының аналитикалық өрнегін білудің маңызы ерекше. Қарапайым биномиалдық және экспоненциал интегралық функцияларды пайдалана отырып, Юлинг потенциалының аналитикалық өрнегін есептеу мүмкіндігі көрсетілген. Келтірілген кестелерден, суреттерден жұмыста алынған аналитикалық өрнек есептеу, зерттеу барысын бірталай жеңілдететіндігін байқауға болады. Юлинг потенциалын есептеу параметрлердің кез келген мәндері үшін іске асырылған. Ұсынылып отырған әдісті кванттық-термодинамикалық есептерді-мәселелерді талдау үшін де пайдалануға болады.
\end{abstract}

Кілт сөздер: Юлинг потенциалы, вакуум поляризациясы, кванттық электродинамика, Бикли-Нейлор функциясы, экспоненциалды интегралдық функция.

\section{Э. Чопуроглу, Т. Мехметоглу}

\section{Аналитическая оценка потенциала Юлинга с использованием теорем биномиального разложения}

В статье введен новый метод изучения потенциала Юлинга с использованием теорем о биномиальном разложении. Отмечено, что потенциал Юлинга является мощным инструментом для определения влияния поляризации вакуума в атомных и мюон-атомных системах. Коррекция поляризации вакуума для электрона в ядерном кулоновском поле может быть более точно определена с помощью потенциала Юлинга. С этой точки зрения определение явных и замкнутых аналитических выражений для потенциала Юлинга очень важно. Представленный метод иллюстрируется аналитическим расчетом потенциала Юлинга с простыми биномиальными коэффициентами и экспоненциальными интегральными функциями. Как видно из таблицы и рисунка, полученное в статье аналитическое выражение позволяет избежать вычислительных трудностей. Оценочный анализ потенциала Юлинга приведен для произвольных значений параметров. Из-за своей простой формы предложенный метод может быть в целом применим к квантово-термодинамическим задачам.

Ключевые слова: потенциал Юлинга, поляризация вакуума, квантовая электродинамика, функции Бикли-Нейлора, экспоненциальная интегральная функция. 